\title{
Analysis of the Humanities Education Strategy in the Course of Appreciation of Film and Television Art
}

Yuan Lu

Zhengzhou Technical College, Zhengzhou 450121, Henan, China. E-mail: luyuan2212@163.com

Abstract: The teaching of film and television art appreciation course aims to cultivate the aesthetic ability and humanistic quality of college students, help college students broaden their cultural horizons and improve their self-innovation ability. This article first discusses the importance of film and television art appreciation courses, and proposes strategies for improving the teaching of film and television art appreciation courses based on humanistic literacy education, in order to improve the quality of course teaching, improve students' ability to appreciate film and television arts, and promote students to form healthy personalities. Improve students' humanistic quality.

Keywords: Film and Television Art Appreciation; Humanistic Accomplishment; Education; Meaning; Strategy

The film and television art appreciation course combines entertainment and the spirit of the times. It has multiple functional attributes such as entertainment and leisure, cultural learning, artistic aesthetics, and ideological education. It is conducive to opening students' mental thinking, allowing students to obtain emotional needs, spiritual comfort, and comprehension of life Philosophy and value meaning. In a rapidly developing society, people's pursuit of material becomes more and more obvious. In contrast, their spiritual level is particularly lacking. Students are susceptible to corruption by money worship and hedonistic ideas, and it is difficult to bear the responsibilities and obligations given by society. However, the existence of film and television art has opened a channel for college students to connect with cultural literacy. Through the study of film and television art appreciation courses, students' influence appreciation ability can be improved, so that students can acquire some healthy, positive and upward personality ideas in film and television dramas. Promote college students to grow into a highquality talent with correct three views and independent personality, so that they can be comprehensively trained to meet the essential needs of quality education.

\section{The great significance of film and television art appreciation courses in the humanities education of college students}

\subsection{Improve college students' aesthetic ability and artistic accomplishment}

The film and television art appreciation course belongs to an art subject. It can embody a kind of artistic aesthetic function, enrich the emotional world of students, improve their ability to appreciate art, and enhance their artistic accomplishment and value. Acquiring artistic influence through the sound, picture, plot, and fragments of film and television works can allow students to improve their internal cultivation, enhance their value taste and aesthetic ability, promote the generation of universities as multi-dimensional talents, and further improve their personal temperament and cultivation. Personality is more sound and perfect.

\subsection{Cultivate the patriotism of college students}

Patriotism education is an important part of quality education, and its focus is to cultivate and promote the national spirit

Copyright $\odot 2020$ Yuan Lu

doi: $10.18686 /$ ahe.v4i10.2902

This is an open-access article distributed under the terms of the Creative Commons Attribution Non-Commercial License (http://creativecommons. org/licenses/by-nc/4.0/), which permits unrestricted non-commercial use, distribution, and reproduction in any medium, provided the original work is properly cited. 
of peace-loving, unity, hard work and bravery. At present, China's film and television industry has achieved rapid development. In recent years, many excellent film and television works have been produced. There is a steady stream of film and television works embodying the spirit of patriotism and collectivism. Students are influenced by good patriotism through appreciation of these films and television works. This is an effective way of national spirit education. While improving the ability of film and television appreciation, students have a deep understanding of the patriotic connotation in film and television works and can extend themselves, invisibly guiding students to actively pay attention to national history, current situation, future trends, and care about national politics, military, economy, etc. Let students take the development of the country's prosperity and strength as their own responsibility, and take practical actions to create value and strength for the country, society, and people.

\subsection{Active students' thinking and improve their innovation ability}

The teaching of film and television art appreciation courses is conducive to extensively activating students' intellectual thinking. Students actively develop their own views and opinions around a certain detail or theme of film and television works, which is conducive to the cultivation of students' divergent thinking. Film and television appreciation is an important part of artistic aesthetics. There are a large number of artistic elements in film and television works. These are the key elements that stimulate students to produce new ideas and new art. In other words, in fact, the study of film and television art appreciation courses should be diversified. Unlike traditional courses, there is no set of solidified teaching mode. The law of learning is to continuously develop multi-level and multi-dimensional thinking, so that students can learn their own culture. The vision and thinking have been expanded and extended, and the ability of self-innovation has been improved. This is also the ultimate goal of the film and television art appreciation course ${ }^{[1]}$.

\section{The improvement strategy of film and television art appreciation courses based on humanistic literacy education}

\subsection{Improve the importance of film and television art appreciation courses}

China's vocational education plan clearly puts forward the importance of quality education, especially under the current social situation, it also advocates that vocational education should focus on cultivating applied interdisciplinary talents. As a vocational college, actively improve the construction of film and television art appreciation courses is education and society the inevitable demand. First of all, the school should strengthen the construction of professional course teaching hardware, and incorporate the film and television art appreciation courses into the overall teaching system; at the same time, it should use campus network platforms, broadcasting platforms, and club organizations to promote film and television art appreciation in the campus culture. Cultivate the functional role of students' humanistic literacy, and enhance the attention and importance of all teachers and students to the curriculum.

\subsection{Improve the curriculum of film and television art appreciation}

Further optimizing the professional curriculum system and continuously adjusting the curriculum settings are effective ways to achieve teaching goals and an important basis for organizing teaching activities. The film and television art appreciation course is different from the general public basic courses. It is an audio-visual course that requires students to truly feel the artistic charm of film and television through vision and hearing, listen carefully to teachers' lectures, watch excellent film and television works, concentrate on film and television works, and finally use film and television knowledge Complete viewing and writing reviews. Such a gradual and orderly course setting from the shallower to the deeper is more in line with the law of college students' cognition of things and conforms to the characteristics of college students' learning, so that the entire course teaching has a theoretical basis and is not empty talk, has a systematic standard and is not boring, has appreciation and observation and is not random, So that students can master the methods of appreciation while increasing their knowledge of film and television art, and promote the improvement of teaching effects ${ }^{[2]}$. In summary, the film and television art appreciation course should not only consider the development of other fields, but also consider the students' cultural background. The curriculum should reflect the advanced and cutting-edge nature, and at the same time, it should not emphasize the systematic rigor of the content. Actually meet the teaching and training goals.

\subsection{Compile applicable textbooks for professional courses}

Applicable course materials are the key to effective teaching and the basic source of students' learning. The film and television art appreciation courses in vocational colleges are mainly carried out in the form of electives or lectures in 
installments. First of all, we must draw up a definite viewing catalog. Teachers need to do the preliminary work, select targeted and representative classic films from a large number of film and television works, and sort out the films that must be watched at each teaching stage according to the class schedule. The works are made into a viewing catalogue, and the selection of film and television works should be as comprehensive as possible, including some feature films, documentaries, disaster films, war films, epic films, etc. In addition, it is necessary to integrate excellent film and television works with courses. Based on the theory of film and television art appreciation courses, students will feel a little boring accordingly. Teachers can intersperse some excellent film and television works to assist teaching while teaching professional curriculum theory. This improves the fun and flexibility of teaching.

Based on the movie catalogue, teachers will prepare course materials with connotation and extension. They should fully compile and organize teaching materials around humanistic literacy education, based on the background connotation, extended thinking, and artistic theory of the film and television works. In-depth teaching guidance is provided in the aspects of screen color, language expression, film and television footage, and appearance of clothing. The teaching content of film and television works is explored to cultivate students' interest in film and television appreciation, enhance the effectiveness of curriculum teaching, and improve humanistic education. As far as students are concerned, an excellent film and television work not only enriches students' inner feelings, but also helps them increase their interest in reading. For example, by allowing students to watch famous films such as "A Dream of Red Mansions" and "The Romance of the Three Kingdoms", students will invisibly increase their interest in understanding original literary works, self-check famous books and improve their personal literary reading ability, which is more conducive to students' self-learning Inquiry ability.

\subsection{Build an excellent professional teaching team}

As mentioned earlier, the film and television art appreciation course is not a general public basic course, nor is it purely for students to watch movies in get out of class and submit film reviews after class. The selection of film and television works needs to be carefully selected, and the appreciation of film and television art needs to be guided step by step. It is necessary to use problem awareness and problem situation creation to fully explore the potential thinking of college students, stimulate students' interest in learning courses, and construct professional teacher assessment and education system. Many of the materials of film and television works are derived from literary creation, so film and television art and literature and art are closely related, which determines that many higher vocational colleges have Chinese teachers as teachers of this course. In order to improve the professionalism and applicability of film and television art appreciation courses, higher vocational colleges should also take the initiative to train some professional film and television art appreciation teachers, and increase corresponding professional teaching training to improve the comprehensive quality and ability of professional teaching; Colleges and universities should actively communicate and interact with film and television professional institutions and other colleges and universities with special expertise, establish a teaching exchange system, and jointly discuss and study film and television art in depth.

\section{Conclusion}

Today when quality education is fully promoted, the teaching of film and television art has also become an important part of the breakthrough test-oriented education. Through the study of film and television appreciation, students' artistic skills, cognitive aesthetics, active thinking, and innovative ability can be improved. Cultivate sentiment, cultivate patriotism, etc., help students establish correct ideological values, release bad emotions, and form a good humanistic spirit. Therefore, higher vocational colleges should actively carry out film and television art appreciation courses, create a good humanistic education environment, inspire and nurture students through course teaching, broaden students' horizons, improve their appreciation capabilities, and let students' thinking fit the spirit of the era's film and television. Guide students to comprehend the spirit of the times and the connotation of film and television works, and promote film and television art appreciation courses to become an effective way to deepen the cultivation of students' humanistic literacy, so that college students can achieve comprehensive development.

\section{References}

1. Li M. The significance of film and television appreciation to the improvement of the humanistic literacy of students in higher vocational colleges. Media Forum 2018; 1(22): 78.

2. Wang M. Suggestions for the establishment of film and television appreciation courses in secondary vocational schools based on humanistic literacy training. Quality Education in West China 2019; 5(8): 52-53. 